\title{
Analysis of Ego Identity Status of School of Physical Education and Sports
}

\author{
Mehmet Behzat Turan*, Kenan Koç, Barış Karaoğlu \\ School of Physical Education and Sports, Erciyes University, Turkey
}

Copyright $\bigcirc 2017$ by authors, all rights reserved. Authors agree that this article remains permanently open access under the terms of the Creative Commons Attribution License 4.0 International License

\begin{abstract}
This study aimed to analyze ego identity status of the candidates who studied in school of physical education and sports. For this purpose, randomly selected 651 individuals, who attended to Kayseri Erciyes University, school of physical education and sports, were included to this study. In this research, Extended Objective Measure of Ego Identity Status scale that was developed by Marcia [1] and adapted to Turkish by Oskay [2] was used to determine volunteers' identity status. Data obtained from personal information form, ego identity status scale was analyzed with SPSS 20.0 package program. For the distribution of the obtained data, Kolmogrov Smirnov test statistics were used and parametric tests were conducted for statistical analyses. Personal information related to candidates was given as scale total scores and frequency (f) and percentage (\%) values were determined. To eliminate the differences between the scores obtained from scales, Independent $t$ test was used for gender variable while One Way Anova test was used for age, mother and father education levels, placing scores of candidates to their departments and higher education variables. As a result, meaningful difference was found between students' ego identity status and their age, education departments, mother education level and placing score to higher education while a meaningful difference was not found between students' ego identity status and gender and father education level. It was thought that students' ego identity status differentiated due to increase in student ages and different interactions of the education departments.
\end{abstract}

Keywords Ego Identity Status, Physical Education, Sports

\section{Introduction}

Identity formation is a dynamic and life-long continuing process. According to Erikson's lifespan development theory; sense of consolidated identity, perceived sense of personal integrity and its continuity are required for an individual to raise his or her functionality up to the highest level [3].

Marcia mainly focused on identity structures' measurability problem and conceptualized identity as structuring of ego as accepted main concepts of Erikson's [4] psychosocial development theory. Considering the variables of searching the alternatives and commitments, Marcia defined four identity statuses. These are as follows; identity achievement, identity moratorium, identity foreclosure, and identity diffusion.

Individuals in identity achievement status stage form commitments as efficiently searches the possible alternatives. Marcia stated that individuals in identity achievement status became determined after the searching period. Individuals in moratorium status do not form specific commitments although they efficiently search the possible alternatives. Those in moratorium identity status were found to be in the searching period and became temporary determined [5]. People in foreclosure identity status create certain commitments however they do not involve in an efficient searching process while creating these commitments. They are not flexible in thinking processes. They enjoy presence of an authority as they like to be told what needs to be done while their approval expectations are high. Other people's thoughts are important for this kind of people. Their toleration for unsuccessfulness is high because they do not identify the target themselves. Foreclosure identity status is a kind of status stage in which least amount of worry is experienced [6].

Individuals in identity diffusion status make temporary searches however do not form any kinds of commitments [6] Diffusion status in which vital decisions are not taken about religious, ideological, occupational and sexual areas, and a search is not performed to reach those kinds of decisions are associated with disadvantageous behaviors such as procrastination behavior [7] and adopting inflexible decision making styles [8].

Erikson determined two opposite characteristics unique to each phase and divided the life into 8 phases. A unique crisis is experienced in each phase and a basic characteristic is obtained after solving the crisis. In each phase, two opposite 
ego characteristics exist however the important phenomenon is that how much these two opposite characteristics evolve into positive direction. According to Erikson's psycho-social development theory, crisis in each phase can be recovered as re-experiencing them in the following development phases [9].

In adolescence period, ego is integrated and individual realizes clearly who she or he is. This realization becomes a sense of identity [10].

Two main factors that Marcia focused on during identity development process are crisis variety and commitment. Crisis is an active period in which adolescent has to make a selection from identity alternatives. Commitment is the end point where adolescent makes the last decision to define himself in association with identity issues. Marcia emphasized that adolescent can choose one of the four identity status [11].

More specifically, adolescents should understand what they want to achieve in their lives and discover which education would be better for themselves, during adolescence period [12]. Discovering and handling this process, they can establish targets for their future, lead their developments and evaluate their transition to adulthood [13].

In Korea, sense of personality of nursing students affected their employment choices after graduation. Those with high level of sense of identity continued nursing while those with low level of sense of identity were prone to leave their occupation [14].

It was determined that during adolescence period, individuals searched for a role for themselves however could not form a commitment to any of the status, furthermore determinacy and stability were started to be observed in individuals and especially in men with a parallel to increase in their ages [15].

There is a meaningful relationship between university students' identity status and their loneliness mean scores [16]. Identity status of university students affects prediction of their learning orientation, performance avoidance orientation and performance approaching orientation. [17] In literature review, it was seen that the number of studies related to ego identity status of university students were very few and especially researches related to students in physical education and sports field were very limited. Our study is expected to contribute and support the literature in this field as offering new and related suggestions. In this context, the purpose of our study was to analyze ego identity status of students in Erciyes University, school of physical education and sports.

\section{Method}

\subsection{Research Group}

A total of 651 students from Erciyes University, School of physical education and sports, as 397 male and 254 female, were included in the study. Participants included in the study were selected with randomly selection method and depending on voluntary basis. In this study, general screening model was used from quantitative research method. In a population consisted of a number of elements, this model screens the whole population or a sample obtained from it in order to reach a general idea about the population [18]

\subsection{Data Collection Tools}

In this research, Personal Information Form and Extended Objective Measure of Ego Identity Status scale were used as data collection tools.

\subsubsection{Socio-demographic information form}

Personal information form that was prepared by the researcher was consisted of participants' gender, age, department, mother-father education levels, placing score to higher education variables.

\subsubsection{Extended Objective Measure of Ego Identity Status Scale; (EOM-EIS)}

Extended Objective Measure of Ego Identity Status scale that was developed by Marcia [1] revised and prepared by Bennion and Adams [3] and adapted to Turkish language by Oskay [2] was used to determine students' identity status. This scale that is consisted of sixty-four items differentiates 4 identity statuses: Identity achievement, moratorium, foreclosure, and identity diffusion. The scale is 6 point Likert type and participants are asked to indicate how much they agree with each item. In the adaptation study, scale's internal consistency coefficiencies varied between 0.57 and 0.84 while test-retest reliability varied between 0.72 and 0.81 . In this study, internal consistency coefficiencies of identity diffusion, foreclosure, moratorium and identity achievement sub-scales were determined as $0.72,0.89,0.80$ and 0.74 , respectively.

\subsection{Data Analysis}

SPSS 20.0 package program was used to analyze data obtained from the scales that were applied in this research. Frequency, median, maximum and minimum values were used in statistical data presentation. Parametric test statistics were utilized due to results distributed normally. Independent Sample $\mathrm{T}$ test was used for gender variable while One Way Anova test was used for age, department, mother-father education and placing score to higher education variables.

\section{Findings}

In Table $1,61 \%$ of participants are male while $39 \%$ of them female. Volunteers' ages are as follows; $58.1 \%$ of them are between $18-21,36.7 \%$ of them are between $22-25$, and $5.2 \%$ of them are between 26-29 ages. Analysis in terms of education departments, $20.6 \%$ study teaching while $28.1 \%$ 
coaching, $24.1 \%$ management and $27.2 \%$ recreation. In terms of mother education level analysis, $75.4 \%$ of them have secondary school level, $10.4 \%$ of them have high school level, $5.7 \%$ of them have associate degree level and $8.4 \%$ of them are university graduate. In father education levels analysis, $62.4 \%$ of them have secondary school level, $22.1 \%$ of them have high school level, $6.6 \%$ of them have associate degree level and $8.9 \%$ of them are university graduate. In terms of students' university entrance exam scores, $19.2 \%$ have scores between $160-200,55.3 \%$ between 201-240, 28.6\% between 241-280, 9.5\% between 281-320 and $6.6 \%$ between $321-360$.

As could be seen in Table 2, a statistically meaningful difference was found in identity achievement sub-scale between age groups and ego identity status of school of physical education and sports. A statistically meaningful difference was found in identity moratorium sub-scale. On the other hand a statistically meaningful difference was not found in identity foreclosure sub-scale. A statistically meaningful difference was found in identity diffusion sub-scale.

As could be seen in Table 3, a statistically meaningful difference was found in identity achievement sub-scale between school departments and ego identity status of school of physical education and sports. A statistically meaningful difference was found in identity moratorium sub-scale. On the other hand a statistically meaningful difference was not found in identity foreclosure sub-scale. A statistically meaningful difference was found in identity diffusion sub-scale.

Table 1. Participants' socio-demographic characteristics

\begin{tabular}{|c|c|c|c|}
\hline & Variables & $\mathbf{N}$ & $\%$ \\
\hline \multirow{2}{*}{ Gender } & Male & 397 & 61.0 \\
\hline & Female & 254 & 39.0 \\
\hline \multirow{3}{*}{ Age } & $18-21$ & 378 & 58.1 \\
\hline & $22-25$ & 239 & 36.7 \\
\hline & $26-29$ & 34 & 5.2 \\
\hline \multirow{4}{*}{ Department } & Teaching & 134 & 20.6 \\
\hline & Coaching & 183 & 28.1 \\
\hline & Management & 157 & 24.1 \\
\hline & Recreation & 177 & 27.2 \\
\hline \multirow{4}{*}{ Mother Education } & Secondary School & 491 & 75,4 \\
\hline & High School & 68 & 10,4 \\
\hline & Associate Degree Program & 37 & 5,7 \\
\hline & Undergraduate & 55 & 8,4 \\
\hline \multirow{4}{*}{ Father Education } & Secondary School & 406 & 62.4 \\
\hline & High School & 144 & 22.1 \\
\hline & Associate Degree Program & 43 & 6.6 \\
\hline & Undergraduate & 58 & 8.9 \\
\hline \multirow{5}{*}{ University Entrance Exam Score } & $160-200$ & 125 & 19.2 \\
\hline & $201-240$ & 235 & 55.3 \\
\hline & $241-280$ & 186 & 28.6 \\
\hline & $281-320$ & 62 & 9.5 \\
\hline & $321-360$ & 43 & 6.6 \\
\hline
\end{tabular}

Table 2. Ego Identity Status Depending on Age

\begin{tabular}{|c|c|c|c|c|c|c|}
\hline Variables & Age & $\mathrm{N}$ & Mean \pm Sd & $\mathrm{F}$ & $\mathrm{P}$ & Meaningful Difference \\
\hline \multirow{3}{*}{ Identity Achievement } & $18-21^{\mathrm{a}}$ & 378 & $4,29 \pm 0,78$ & \multirow{3}{*}{12,508} & \multirow{3}{*}{, 000} & \multirow{3}{*}{$\begin{array}{l}a-b \\
b-c\end{array}$} \\
\hline & $22-25^{\mathrm{b}}$ & 239 & $4,55 \pm 0,74$ & & & \\
\hline & $26-29^{c}$ & 34 & $4,02 \pm 0,73$ & & & \\
\hline \multirow{3}{*}{ Identity Moratorium } & $18-21^{\mathrm{a}}$ & 378 & $3,14 \pm 0,97$ & \multirow{3}{*}{11,545} & \multirow{3}{*}{, 000} & \multirow{3}{*}{$\begin{array}{l}a-b \\
b-c\end{array}$} \\
\hline & $22-25^{\mathrm{b}}$ & 239 & $3,50 \pm 0,97$ & & & \\
\hline & $26-29^{c}$ & 34 & $2,99 \pm 0,91$ & & & \\
\hline \multirow{3}{*}{ Identity Foreclosure } & $18-21^{\mathrm{a}}$ & 378 & $2,90 \pm 1,11$ & \multirow{3}{*}{1,444} & \multirow{3}{*}{, 237} & \multirow{3}{*}{-} \\
\hline & $22-25^{\mathrm{b}}$ & 239 & $3,02 \pm 1,13$ & & & \\
\hline & $26-29^{c}$ & 34 & $2,73 \pm 1,04$ & & & \\
\hline \multirow{3}{*}{ Identity Diffusion } & $18-21^{\mathrm{a}}$ & 378 & $2,99 \pm 0,91$ & \multirow{3}{*}{6,002} & \multirow{3}{*}{, 003} & \multirow{3}{*}{$\begin{array}{l}a-b \\
b-c\end{array}$} \\
\hline & $22-25^{\mathrm{b}}$ & 239 & $3,22 \pm 1,02$ & & & \\
\hline & $26-29^{c}$ & 34 & $2,78 \pm 0,89$ & & & \\
\hline
\end{tabular}


Table 3. Ego Identity Status Depending on School Departments

\begin{tabular}{|c|c|c|c|c|c|c|}
\hline Variables & Department & $\mathrm{N}$ & $\operatorname{Mean} \pm \mathrm{Sd}$ & $\mathrm{F}$ & $\mathrm{P}$ & Meaningful Difference \\
\hline \multirow{4}{*}{ Identity Achievement } & Teaching $^{\mathrm{a}}$ & 134 & $4,20 \pm 0,07$ & \multirow{4}{*}{6,107} & \multirow{4}{*}{, 000} & \multirow{4}{*}{$\begin{array}{l}a-c \\
a-d \\
b-d\end{array}$} \\
\hline & Coaching $^{\mathrm{b}}$ & 183 & $4,27 \pm 0,05$ & & & \\
\hline & Management $^{\mathrm{c}}$ & 157 & $4,48 \pm 0,07$ & & & \\
\hline & Recreation $^{\mathrm{d}}$ & 177 & $4,50 \pm 0,06$ & & & \\
\hline \multirow{4}{*}{ Identity Moratorium } & Teaching $^{\mathrm{a}}$ & 134 & $3,05 \pm 0,07$ & \multirow{4}{*}{3,496} & \multirow{4}{*}{, 015} & \multirow{4}{*}{$\begin{array}{l}\text { a-c } \\
\text { a-d }\end{array}$} \\
\hline & Coaching $^{\mathrm{b}}$ & 183 & $3,24 \pm 0,07$ & & & \\
\hline & Management $^{\mathrm{c}}$ & 157 & $3,36 \pm 0,08$ & & & \\
\hline & Recreation $^{\mathrm{d}}$ & 177 & $3,38 \pm 0,07$ & & & \\
\hline \multirow{4}{*}{ Identity Foreclosure } & Teaching $^{\mathrm{a}}$ & 134 & $2,77 \pm 0,09$ & \multirow{4}{*}{1,310} & \multirow{4}{*}{,270 } & \multirow{4}{*}{-} \\
\hline & Coaching $^{\mathrm{b}}$ & 183 & $2,93 \pm 0,09$ & & & \\
\hline & Management $^{\mathrm{c}}$ & 157 & $3,00 \pm 0,09$ & & & \\
\hline & Recreation $^{\mathrm{d}}$ & 177 & $3,00 \pm 0,08$ & & & \\
\hline \multirow{4}{*}{ Identity Diffusion } & Teaching $^{\mathrm{a}}$ & 134 & $2,87 \pm 0,06$ & \multirow{4}{*}{4,278} & \multirow{4}{*}{,005 } & \multirow{4}{*}{$\begin{array}{l}\mathrm{a}-\mathrm{c} \\
\mathrm{a}-\mathrm{d}\end{array}$} \\
\hline & Coaching $^{\mathrm{b}}$ & 183 & $2,99 \pm 0,07$ & & & \\
\hline & Management $^{\mathrm{c}}$ & 157 & $3,22 \pm 0,08$ & & & \\
\hline & Recreation $^{\mathrm{d}}$ & 177 & $3,15 \pm 0,08$ & & & \\
\hline
\end{tabular}

Table 4. Ego Identity Status Depending on Mother Education Levels

\begin{tabular}{|c|c|c|c|c|c|c|}
\hline Variables & $\begin{array}{l}\text { Mother Education } \\
\text { Levels }\end{array}$ & $\mathrm{N}$ & Mean $\pm \mathrm{Sd}$ & $\mathrm{F}$ & $\mathrm{P}$ & Meaningful Difference \\
\hline \multirow{4}{*}{ Identity Achievement } & Secondary School ${ }^{\mathrm{a}}$ & 491 & $4,35 \pm 0,77$ & \multirow{4}{*}{2,562} & \multirow{4}{*}{, 054} & \multirow{4}{*}{-} \\
\hline & High School $^{\mathrm{b}}$ & 68 & $4,60 \pm 0,74$ & & & \\
\hline & $\begin{array}{l}\text { Associate Degree } \\
\text { Program }^{c}\end{array}$ & 37 & $4,23 \pm 0,66$ & & & \\
\hline & Undergraduate $^{\mathrm{d}}$ & 55 & $4,42 \pm 0,86$ & & & \\
\hline \multirow{4}{*}{ Identity Moratorium } & Secondary School ${ }^{\mathrm{a}}$ & 491 & $3,28 \pm 0,95$ & \multirow{4}{*}{4,725} & \multirow{4}{*}{, 003} & \multirow{4}{*}{$\begin{array}{l}\text { b-c } \\
b-d\end{array}$} \\
\hline & High School $^{\mathrm{b}}$ & 68 & $3,56 \pm 1,24$ & & & \\
\hline & $\begin{array}{l}\text { Associate Degree } \\
\text { Program }^{\mathrm{c}}\end{array}$ & 37 & $2,94 \pm 0,95$ & & & \\
\hline & Undergraduate $^{\mathrm{d}}$ & 55 & $3,01 \pm 0,80$ & & & \\
\hline \multirow[t]{4}{*}{ Identity Foreclosure } & Secondary School ${ }^{\mathrm{a}}$ & 491 & $2,92 \pm 1,07$ & 2,537 & 056 & \multirow{4}{*}{$b-c$} \\
\hline & High School $^{\mathrm{b}}$ & 68 & $3,13 \pm 1,34$ & & & \\
\hline & $\begin{array}{l}\text { Associate Degree } \\
\text { Program }^{\mathrm{c}}\end{array}$ & 37 & $2,52 \pm 1,19$ & & & \\
\hline & Undergraduate $^{\mathrm{d}}$ & 55 & $3,03 \pm 1,12$ & & & \\
\hline \multirow{4}{*}{ Identity Diffusion } & Secondary School ${ }^{\mathrm{a}}$ & 491 & $3,04 \pm 0,93$ & \multirow{4}{*}{3,905} & \multirow{4}{*}{, 009} & \multirow{4}{*}{$\begin{array}{l}a-b \\
b-c\end{array}$} \\
\hline & High School $^{\mathrm{b}}$ & 68 & $3,40 \pm 1,22$ & & & \\
\hline & $\begin{array}{l}\text { Associate Degree } \\
\text { Program }^{c}\end{array}$ & 37 & $2,80 \pm 0,98$ & & & \\
\hline & Undergraduate $^{\mathrm{d}}$ & 55 & $3,01 \pm 0,70$ & & & \\
\hline
\end{tabular}

In Table 4, mother education levels do not have a statistically meaningful effect on identity achievement status. Meaningful difference could be observed in identity moratorium sub-scale. A relatively difference could be observed in identity foreclosure status. Additionally, a difference in terms of mother education levels could be seen in identity diffusion sub-scale.

In Table 5, father education levels were observed to have a statistically meaningful effect on only identity diffusion sub-scale and secondary school and undergraduate levels in terms of ego identity status while a statistically meaningful difference was not found in other sub-scales and education levels.

In Table 6, placing score to higher education does not have a meaningful difference in any of sub-scales of identity status. 
Table 5. Ego Identity Status Depending on Father Education Levels

\begin{tabular}{|c|c|c|c|c|c|c|}
\hline Variables & $\begin{array}{c}\text { Father Education } \\
\text { Levels }\end{array}$ & $\mathrm{N}$ & Mean $\pm \mathrm{Sd}$ & $\mathrm{F}$ & $\mathrm{P}$ & Meaningful Difference \\
\hline \multirow{4}{*}{ Identity Achievement } & Secondary School ${ }^{a}$ & 406 & $4,34 \pm 0,77$ & \multirow{4}{*}{, 814} & \multirow{4}{*}{,486 } & \multirow{4}{*}{-} \\
\hline & High School $^{\mathrm{b}}$ & 144 & $4,42 \pm 0,82$ & & & \\
\hline & $\begin{array}{l}\text { Associate Degree } \\
\text { Program }^{\mathrm{c}}\end{array}$ & 43 & $4,44 \pm 0,69$ & & & \\
\hline & Undergraduate $^{\mathrm{d}}$ & 58 & $4,46 \pm 0,74$ & & & \\
\hline \multirow[t]{2}{*}{ Identity Moratorium } & Secondary School ${ }^{\mathrm{a}}$ & 406 & $3,22 \pm 0,96$ & 1,893 &, 129 & \multirow{4}{*}{-} \\
\hline & High School $^{b}$ & 144 & $3,34 \pm 1.01$ & & & \\
\hline \multirow[t]{2}{*}{ - } & $\begin{array}{l}\text { Associate Degree } \\
\text { Program }^{\mathrm{c}}\end{array}$ & 43 & $3,14 \pm 0,89$ & & & \\
\hline & Undergraduate $^{\mathrm{d}}$ & 58 & $3,50 \pm 1.07$ & & & \\
\hline Identity Foreclosure & Secondary School ${ }^{\mathrm{a}}$ & 406 & $2,94 \pm 1,09$ &, 747 &, 524 & \multirow{4}{*}{ - } \\
\hline & High School $^{\mathrm{b}}$ & 144 & $2,92 \pm 1,21$ & & & \\
\hline & $\begin{array}{l}\text { Associate Degree } \\
\text { Program }^{\mathrm{c}}\end{array}$ & 43 & $2,73 \pm 1,08$ & & & \\
\hline & Undergraduate $^{\mathrm{d}}$ & 58 & $3,06 \pm 1,05$ & & & \\
\hline \multirow{4}{*}{ Identity Diffusion } & Secondary School ${ }^{\mathrm{a}}$ & 406 & $3,00 \pm 0,92$ & \multirow{4}{*}{2,753} & \multirow{4}{*}{,042 } & \multirow{4}{*}{$a-d$} \\
\hline & High School $^{\mathrm{b}}$ & 144 & $3,10 \pm 1,01$ & & & \\
\hline & $\begin{array}{l}\text { Associate Degree } \\
\text { Program }^{\mathrm{c}}\end{array}$ & 43 & $3,10 \pm 0,91$ & & & \\
\hline & Undergraduate $^{\mathrm{d}}$ & 58 & $3,38 \pm 1,04$ & & & \\
\hline
\end{tabular}

Table 6. Ego Identity Status Depending on Placing Score to Higher Education

\begin{tabular}{|c|c|c|c|c|c|c|}
\hline Variables & $\begin{array}{c}\text { University } \\
\text { Entrance Exam } \\
\text { Score } \\
\end{array}$ & $\mathrm{N}$ & Mean $\pm \mathrm{Sd}$ & $\mathrm{F}$ & $\mathrm{P}$ & Meaningful Difference \\
\hline \multirow{5}{*}{ Identity Achievement } & $160-200^{\mathrm{a}}$ & 125 & $4,44 \pm 0,82$ & \multirow{5}{*}{1,494} & \multirow{5}{*}{,202 } & \multirow{5}{*}{-} \\
\hline & $201-240^{b}$ & 235 & $4,38 \pm 0,72$ & & & \\
\hline & $241-280^{c}$ & 186 & $4,32 \pm 0,82$ & & & \\
\hline & $281-320^{\mathrm{d}}$ & 62 & $4,23 \pm 0,83$ & & & \\
\hline & $321-360^{\mathrm{e}}$ & 43 & $4,55 \pm 0,61$ & & & \\
\hline \multirow[t]{5}{*}{ Identity Moratorium } & $160-200^{\mathrm{a}}$ & 125 & $3,26 \pm 1,00$ & 1,770 & ,133 & \multirow[t]{5}{*}{-} \\
\hline & $201-240^{\mathrm{b}}$ & 235 & $3,20 \pm 0,97$ & & & \\
\hline & $241-280^{c}$ & 186 & $3,27 \pm 0,96$ & & & \\
\hline & $281-320^{\mathrm{d}}$ & 62 & $3,26 \pm 0,98$ & & & \\
\hline & $321-360^{\mathrm{e}}$ & 43 & $3,63 \pm 1,06$ & & & \\
\hline \multirow[t]{5}{*}{ Identity Foreclosure } & $160-200^{\mathrm{a}}$ & 125 & $2,91 \pm 1,05$ & 1,551 & , 186 & \multirow{5}{*}{-} \\
\hline & $201-240^{\mathrm{b}}$ & 235 & $2,83 \pm 1,13$ & & & \\
\hline & $241-280^{c}$ & 186 & $2,96 \pm 1,08$ & & & \\
\hline & $281-320^{\mathrm{d}}$ & 62 & $3,03 \pm 1,23$ & & & \\
\hline & $321-360^{\mathrm{e}}$ & 43 & $3,26 \pm 1,18$ & & & \\
\hline \multirow{5}{*}{ Identity Diffusion } & $160-200^{\mathrm{a}}$ & 125 & $3,04 \pm 1,09$ & \multirow{5}{*}{, 889} & \multirow{5}{*}{, 470} & \multirow{5}{*}{-} \\
\hline & $201-240^{\mathrm{b}}$ & 235 & $3,02 \pm 0,98$ & & & \\
\hline & $241-280^{c}$ & 186 & $3,08 \pm 0,87$ & & & \\
\hline & $281-320^{\mathrm{d}}$ & 62 & $3,06 \pm 0,67$ & & & \\
\hline & $321-360^{\mathrm{e}}$ & 43 & $3,31 \pm 1,09$ & & & \\
\hline
\end{tabular}


Table 7. Ego Identity Status Depending on Gender

\begin{tabular}{|c|c|c|c|c|c|c|}
\hline Variables & Gender & $\mathrm{N}$ & Mean \pm Sd & $\mathrm{t}$ & $\mathrm{F}$ & $\mathrm{P}$ \\
\hline \multirow{2}{*}{ Identity Achievement } & Male & 397 & $4.37 \pm 0,79$ & \multirow{2}{*}{-.04} & \multirow{2}{*}{,649 } & \multirow{2}{*}{.962} \\
\hline & Female & 254 & $4.38 \pm 0,76$ & & & \\
\hline \multirow{2}{*}{ Identity Moratorium } & Male & 397 & $3,30 \pm 0,98$ & \multirow{2}{*}{1.18} & \multirow{2}{*}{,649 } & \multirow{2}{*}{.238} \\
\hline & Female & 254 & $3,21 \pm 0,98$ & & & \\
\hline \multirow{2}{*}{ Identity Foreclosure } & Male & 397 & $3.00 \pm 1.10$ & \multirow{2}{*}{1.88} & \multirow{2}{*}{,649 } & \multirow{2}{*}{.060} \\
\hline & Female & 254 & $2.82 \pm 1.12$ & & & \\
\hline \multirow{2}{*}{ Identity Diffusion } & Male & 397 & $3.04 \pm 099$ & \multirow{2}{*}{-.77} & \multirow{2}{*}{,649 } & \multirow{2}{*}{.441} \\
\hline & Female & 254 & $3.09 \pm 0,90$ & & & \\
\hline
\end{tabular}

In Table 7, gender does not create a statistically meaningful difference in ego identity status. In any of sub-scales, a statistically meaningful difference was not found between male and female.

\section{Discussion and Conclusions}

As a result of the analyses conducted in direction of the main purpose of this research, means of identity achievement increase with parallel to increase in ages while means of identity moratorium, identity diffusion and identity foreclosure decrease. Students' scores in identity foreclosure decrease as they get older. In the analysis of findings related to age variable, identity foreclosure scores decrease with an increase in age. [19]. Marcia [1] emphasized that identity status was in a developmental continuity and development was expected to evolve from identity diffusion and identity foreclosure sub-scales to identity achievement. Transition to identity achievement status is experienced with an increase in age [20] In a similar study, Akar [21] found out that a meaningful difference between university students' identity status and gender was not observed. Identity crises reduce from the years of high school to university and the fact that age is among the social capital variables that predict identity supports this phenomenon [22].

In the analysis of data in terms of university departments, identity achievement status in recreation and management departments were found higher. The fact that mainly communication oriented and applied courses are taken in these departments, internship programs are completed in mainly interactive constitutions such as hotels, municipalities and sports directorates, and indirectly social interaction opportunities of students in these departments are higher is thought to contribute to this result [23]. Increase or decrease in needs of sufficiency, making a relationship and autonomy has a crucial connection with the university departments which students attend. It is thought that formation of identity achievement in coaching and teaching departments might be affected negatively in terms of job anxiety and occupational sense. In a similar study [24], physical education teacher candidates' attitudes toward teaching occupation and their occupational liking levels were not found to be sufficient. Additionally, their occupational anxiety levels were observed in higher levels than it should be.

In terms of identity moratorium, identity foreclosure and identity diffusion, the highest mean scores were found recreation and management department students. [25] It could be said that with an increase in despair levels of school of physical education and sports students, foreclosure behavior levels increase [26]. In the analysis of coherence level between ego and occupational ego concepts in terms of the people who had effects on selecting sport management department, a meaningful difference was not found between individuals who selected sport management department with own decisions and individuals who selected this department with their families, friends or teachers intervention. This condition reflects identity foreclosure status [27]. Recreation department students stated that they learnt recreation while preparing for special ability tests or entering to department however this department did not take place in their career plans. Therefore, results show that students relatively get familiar with studies related to recreation during their university periods however they do not think about pursuing a career in recreation field. It is widely known that students in this department experience anxiety since there are limited number of opportunities for new graduates to find a job in this area. This condition gives rise the idea that they would look for new opportunities for their future or evolve themselves into identity achievement.

The fact that teaching and coaching department students' academic successes are higher than others, job opportunities are more and students generally do sports in active manner as obtaining necessary license is thought to contribute them to complete successfully the process of identity search. In early adulthood period, individuals in identity achievement status should adapt with societal expectations although they reach permanent determination levels and take their own decisions. Today, even university education is not sufficient for individuals to find a job depending on their expectations and to make their own livings, competitive structure of business world, high level of societal expectations might cause that individuals' behaviors are shaped by environmental conditions although they reach identity achievement status. 
In other words, individuals might encounter external factors which increase their anxiety although they take decisions by themselves. This condition gives rise to young adults' anxiety levels although they have identity achievement status [20].

Mother-father education levels generally affect individuals' personal development. It is thought that especially mother education level is crucial for individuals' self-realization process. In the analysis of identity moratorium, identity foreclosure and identity diffusion status in our study, it was found that children of mothers with university degree had lower means for the related status. Identity moratorium status means of adolescences from mothers with primary school degree were found meaningfully higher compared to identity moratorium status means of adolescences from mothers with university or higher education levels [28]. A family environment is important where children's demands and development levels are taken into account, tolerance, understanding and restrictions are balanced [29]. It was determined that mothers and fathers with high level of education had democratic attitudes. It was determined that children of mother and fathers, who had democratic attitudes, had high level of academic successes and problem-solving abilities while their social anxiety levels were low [30]. Some studies show that mothers' education levels are effective in mother and father attitudes.

In a study where Bozaslan and Kaya [30] analyzed attitudes of Harran University students' mothers and fathers in terms of their problem solving abilities, social anxiety and academic success, they determined that mothers and fathers who had high level of education levels had democratic attitudes. In this context, it could be said that individuals' parents can provide autonomy opportunities for adolescents and they guide adolescents while providing them necessary freedom as parents obtain democratic attitudes with their education levels increase [31] hence parents can help adolescents in their identity obtaining process.

In terms of placing score to higher education, a meaningful difference was not observed between ego identity status sub-scales. Similar results can be found in literature; Özdamar et al [32] could not find a meaningful relationship between psycho-social orientation and university entrance exam score. [33] A relationship was not found between university entrance score and physical education teaching occupational attitudes and orientation. Additionally, Bozaslan and Kaya [30] it was found out that university entrance exam score was not associated with successes in theory learning and applications in sports schools. The fact that there is not a major difference between entrance scores to departments in school of physical education and sports and minimum score of application to study in these schools is low might cause that a meaningful difference is not found between departments.

In our study, a significant difference could not found for any of sub-scales in terms of genders. It was observed that there has not been a consensus in literature about the effect on gender in identity status [34] determined that women had higher scores in identity achievement than men did and [6] found out that men had higher scores in identity diffusion than women. On the other hand, Yunus et al. [35] stated that men had higher scores in identity achievement status while women had higher scores for identity searching process. Kennedy [36] determined that men had higher mean values in identity diffusion and identity achievement compared to women's mean scores. Gönül [20] could not find a meaningful relationship between genders. In a meta-analysis study that was conducted in this subject, Kroger [37] it was found out that a gender-based differentiation did not exist in identity status however, women had higher scores for some of sub-scales (i.e. sexuality and family roles) than men did. Therefore Kroger stated that in the studies to be made in identity development subject, it would be more beneficial to consider gender roles instead of gender.

As a result, a meaningful difference was found between students' ego identity status and their age, university department, mother education level and placing score to higher education while a meaningful difference was not found between students' ego identity status and their gender and father education level.

It is thought that students' ego identity status differentiate due to an increase in students' age, different interactions that are provided in university departments.

\section{Suggestions}

- This study was conducted in Erciyes University, School of Physical Education and Sports. The population of the future studies can be extended and similar studies can be compared.

- Participants might be informed about ego identity status.

- Education environments with which participants can express themselves comfortable can be created.

- Applications that help participants in self-actualization process, motivate them and help them realize their abilities can be used.

\section{REFERENCES}

[1] J.E. Marcia (1966). Development and validation of Ego-Identity status. Journal of Personality and social psychology, 3, 551-558.

[2] G. Oskay (1998). Extended objective measure Of Ego Identity Status-EOM-EIS' İn Turkceye Uyarlanması. Türk Psikolojik Danışma Ve Rehberlik Dergisi, 2(9), 17-24

[3] G.R. Adams, M.D. Berzonsky \& L. Keating (2006) Psychosocial Resources in First-Year University students: The Role Of İdentity processes and social relationships. Journal of Youth and adolescence, 35 (1), 81-91. 
[4] K. Erikson (1966). Wayward Puritans: A Study in the Sociology of Deviance. New York. John Wiley and Sons

[5] H.N. Çelen, (2007). Ergenlik Ve Genç Yetişkinlik, İstanbul: Papatya Yayıncilık.

[6] Ü. Morsünbül \& B. Tümen (2008) Ergenlik Döneminde Kimlik Ve Bağlanma İlişkileri: Kimlik Statüleri Ve Bağlanma Stilleri Üzerinden Bir İnceleme. Cocuk Ve Gençlik Ruh Sağlığı Dergisi, 15 (1),

[7] M. Shanahan \& T.A. Pychyl (2007). An Ego İdentity perspective On Volitional action: Identity Status, Agency, and procrastination. Personality and individual differences, 43, 901-911.

[8] F. Bacanl1 (2012) An Examination Of The relationship amongst decision-Making strategies and Ego Identity statuses. Karar Verme Stratejileri Ve Ego Kimlik Statüleri Arasındaki İlişkilerin İncelenmesi. Eğitim Ve Bilim, 37(163), 17-28.

[9] H. Atak (2005).Beliren Yetişkinlik: Yeni Bir Yaşam Döneminin Türkiye'de İncelenmesi, Yayımlanmamış Yüksek Lisans Tezi, Ankara Üniversitesi Eğitimbilimleri Enstitüsü

[10] E. Arslan \& R. Arı (2008). Ego Kimlik Süreci Ölçeğinin Türkçeye Uyarlama Güvenirlik Ve Geçerlik Çalışması. S.Ü. Sosyal Bilimler Enstitüsü Dergisi, 20, 75-

[11] Y. Akman. (2007) Identity Status of Turkish University Students İn Relation To The İrevaluation Of Family Problems. Social Behavior And Personality, 35 (1), 79-85

[12] V.Skorikov \& F.W. Vondracek (2011). Occupational identity. In S. J. Schwartz, K. Luyckx, \& V. L. Vignoles (Eds.), Handbook Of Identity theory and research. New York: Springer

[13] B. Duriez, K. Luyckx, B. Soenens, \& M.D.A. Berzonsky (2012). Process-Content approach to adolescent identity formation: Examining longitudinal associations between identity styles and goal pursuits. Journal Of Personality, 80, $135-161$

[14] J.A. Galles, J.G. Lenz (2013) Relationships among Career Thoughts, Vocational İdentity, And Calling: İmplications For Practice. Career Dev Q. ;61(3):240e8.

[15] W William, III Hale, A. Quinten, W. Raaijmakers, J.Susan, T. Branje (2010). Identity Formation in Adolescence: Change or Stability Journal of Youth and Adolescence 39:150-162

[16] C. Arslan, E Hamarta , Z. Özyeşil, Y. Saygın. (2011) Selçuk Üniversitesi Ahmet Keleşoğlu Eğitim Fakültesi Dergisi Say1 31, Ss 89-99

[17] S. Özgüngör (2014), Relationship Between Identity Statuses and Goal Orientations Based on University Students' Self Esteem Levels Pamukkale Üniversitesi Eğitim Fakültesi Dergisi, Say1 35 Ss. 33-46.

[18] N. Karasar (2015) Bilimsel Araştırma Yöntemi,28.Baskı Ankara:Nobel Yayın Dağıtım

[19] İ. Demir (2009). Çocuk Ve Gençlik Ruh Sağlığı Dergisi, 16(3):129-136

[20] E. Gönül. (2008) Kimlik Statülerinin 22-30 Yaşlar Arasındaki Genç Yetişkinlerin Yaşadığı Kaygı Düzeyi İle İlișkisi,Yayınlanmamıș Yüksek Lisans Tezi Sosyal Bilimler Enstitüsü ,Maltepe Üniversitesi
[21] A. Akar (2012). Üniversite Öğrencilerinin Kimlik Statüleri İle Bağlanma Stilleri Arasındaki İlişkinin İncelenmesi, Yayınlanmamış Yüksek Lisans Tezi, İstanbul: Maltepe Üniversitesi Sosyal Bilimler Enstitüsü

[22] F.Dereboy, N. Çelen (2012) Çocuk Ve Gençlik Psikiyatrisi Yayınlar1, 83-119

[23] Y. Yavuz (2016). Beden Eğitimi Ve Spor Yüksekokulu Öğrencilerinin Temel Psikolojik İhtiyaçlarının Bazı Değişkenlere Göre İncelenmesi ,Yayınlanmamış Yksek Lisans Tezi Kahramanmaraş Sütçü İmam Üniversitesi ,Sağlık Bilimleri Enstitüsü

[24] Y. Bakırcı (2015) Beden Eğitimi Öğretmen Adaylarının Öğretmenlik Mesleğine Yönelik Tutumlarının İncelenmesi, Yayınlanmamış Yüksek Lisans Tezi, Aksaray Üniversitesi Sosyal Bilimler Enstitüsü

[25] M. Tekin K. Filiz (2008). Beden Eğitimi Ve Spor Yüksekokullarının Antrenörlük Eğitimi Ve Spor Yöneticiliği Bölümlerinde Öğrenim Gören Öğrencilerin Umutsuzluk Ve Boyun Eğici Davranış Düzeylerinin Çeşitli Değişkenlere Göre İncelenmesi, Spormetre Beden Eğitimi Ve Spor Bilimleri Dergisi, V1 (1) 27-37

[26] Y. Y1ldı (2004).Celal Bayar Üniversitesi Yöneticilik Bölümünde Öğrenim Gören Spor Yöneticisi Adayların Benlik Ve Mesleki Benlik Kavramları Arasında Ki Bağdaşım Düzeyinin Bazı Faktörler Açısından İncelenmesi Yayınlanmamıș Yüksek Lisans Tezi Celal Bayar Üniversitesi, Sağlık Bilimleri Enstitüsü

[27] K. Öcal (2016) Predictors Of Academic Procrastination And University Life Satisfaction Among Turkish Sport Schools Students, Academic Journals Education Research And Reviews Vol.11(7), Pp. 482-490

[28] N. Baş (2013) Ergenlerin Bağlanma Stilleri Ve Kimlik Statüleri Arasındaki İlişkinin İncelenmesi, Yayınlanmamış Yüksek Lisans Tezi Çukurova Üniversitesi Sosyal Bilimler Enstitüsü

[29] Ö. Sezer (2010). Ergenlerin Kendilik Algılarının Anne Baba Tutumları Ve Bazı Faktörlerle İlișkisi.Yüzüncü Yıl Üniversitesi, Eğitim Fakültesi Dergisi, Cilt: 7, Sayı:1, 1-19.

[30] A Kaya, H. Bozaslan,G. Genç (2012) Dicle Üniversitesi Ziya Gökalp Eğitim Fakültesi Dergisi, 18 208-225

[31] B. İnanç Yazgan, M. Bilgin \& K. Atıc1. (2005) Gelişim Psikolojisi Çocuk Ve Ergen Gelişimi (5. Bask1). Adana: Nobel Kitabevi.

[32] G. Özdamar, E.N. Ada, Z. Pehlivan (2016) Beden Eğitimi Öğretmen Adaylarının Erikson'unPsiko-Sosyal Gelişim Dönemlerine Ait Kazanımlarının İncelenmesi, Journal Of Sports And performance researches Vol:7 No:2 Pg:103-111

[33] N. Toprak, L. Saraç (2014). Beden Eğitimi Ve Spor Yüksekokulu Özel Yetenek Sinavı'na Başvuran Kadın Ve Erkek Adayların Öğretmenlik Mesleğine Karşı Tutumlarının Karşıllaştırılması Pamukkale Journal Of Sport sciences, Vol.5, No.2, Pg:35-47

[34] G. Özdikmenli Demir (2010). Üniversite Öğrencilerinde Kimlik Gelişimi: Kimlik Statülerinin Sosyal Sermaye Ve Kimlik Sermayesi İle Olan İlişkisi. Çukurova Üniversitesi Sosyal Bilimler Dergisi, 34, 1-10. 
[35] F. Yunus, W.A. Kamal, A. Jusoff, A. Zakaria (2010).Gender Differences On The İdentity Status of the Malaysian Preparatory Students. Canadian Social Science. 6, 145-151
[36] H. Kennedy (1999). Romantic attachment style and Ego İdentity, Attritional style and family Of Origin İn First-Year college students. College student journal, 33,171-180.

[37] J. Kroger (1997). Gender and identity: The intersection Of Structure, Content, and context. Sex roles, 36, 747-770. 